\title{
Consumer Cooperatives, Food Security and Sustainability among Civil Servants in Ekiti State, Nigeria
}

\author{
Adedapo A. $\mathrm{O}^{1}$, Alabi O. $\mathrm{O}^{2}$ \\ ${ }^{I}$ Department of Extension Education, DrBalasaheebSawantKonkanKrishiVidyapeeth,Dapoli - 415712 Dist: \\ Ratnagiri(Maharasthra State) India. \\ ${ }^{2}$ Department of Agricultural Economics and Extension, Faculty of Agricultural Sciences, Federal University \\ OyeEkiti, P.M.B 373 OyeEkiti, Ekiti State, Nigeria.
}

\begin{abstract}
The issues of food security and family sustenance have been a major challenge in recent times due to the importance of food as the basic necessity of life. A large number of urban dwellers have not been able to meet the need of food for family consumption. Due to urban development, there is inadequate access of land for subsistence farming.In order to find solution to this food crisis, civil servants have resulted into consumer cooperative which involved the bulk purchase of food items for members, in which food are purchased on loans and then deducted from their salaries. This study access the influence of cooperative on household food security and sustainability among civil servants in Ekiti state. A total of 120 civil servants were randomly selected for the study. Findings revealed that $88.33 \%$ (106 people) of the respondents patronize consumer cooperatives, $60.37 \%$ patronize mainly during the festive periods, $31.64 \%$ patronized on monthly basis while only $8.49 \%$ patronize on quarterly basis. The main reason for patronizing consumer cooperative is purchase of food items at cheaper price compare to market price and the convenience of payment. Result of the probit model shows the significant relationship between consumer cooperatives and household food security, a positive significant relationship between the level of education, level of income and household food security among civil servant in Ekiti state. However, there is a negative relationship between household size and food security, indicating that increase in household size has a corresponding influence on the level of food insecurity.
\end{abstract}

Keywords: Civil servants, consumer co-operatives, food security, poverty, sustainability.

\section{Introduction}

The issues of food security and family sustenance have been a major challenge in recent times due to the importance of food as the basic necessity of life. A large number of urban dwellers have not been able to meet the basic need of food for family consumption [1]. Due to urban development, there is inadequate access of land for subsistence farming. The challenge of food insecurity has become a global debate due to shortage of food to meet the needs for human consumption with over one billion people going starving [2]. Distinctively, approximately $70 \%$ of Nigerians are food insecure, which implies that more than half of the population does not have access to quantitative and nutritious food for a healthy and productive life. There are manace of starving and poverty in the nation with more than half of the people living far below 100 (US \$ 0.6) per day[3]. In February 2008, Government of Nigeria released about 80 billion for importation of food items when the challenge of food shortage arose[3] and this depicts the level of food insecurity in the country. However, food security is when people, have sufficient access to nutritious food at all times [4], to meet their dietary requirement and food preferences for active and healthy life [2].

Food availability at household level demands through own production or purchase from the market. Therefore, the issue of food received by households is a necessity for household's food security and food production functions, market efficiency and household income level [5]. More than half of Nigerian population is food insecure due to low minimum wages, despite the importation of food items they were handicap in terms of purchasing capacity. In order to avert the inadequate supply of food to meet the requirement of family consumption, cooperative societies were seen as a possible option due to the role it plays in distribution of food for family consumption among its members. It helps in gathering, processing, distribution, consumed and disposal of food to the populace.

Cooperatives are owned and governed by members, who pool resources together to achieve a common goal for the benefit of their members in line with the laid down principle commonly agreed by them. This is also seen as a prerequisite for food security and sustainable development due to the form of cooperative as consumer cooperatives, producer cooperatives and/or worker cooperatives. A Consumers' cooperative is one in which individuals combine their purchasing capacity, for the purchase and distribution of agricultural commodities and other products. However, cooperative societies are practical conveyance for cooperation and joint action, which is one of the necessities for sustainable development. Cooperative has contributed tremendously to the actualization of Millennium Development Goals (MDGs) mostly in developing countries [6]. This study access 
consumer cooperatives, food security and sustainability among civil servants in Ekiti state, with the objectives of assessing the influence of cooperative on food security, reasons for patronizing cooperative society for household food and other consumer's need, ranking the importance of cooperative to household food security and consumer's need and also the significant relationship between the socio economic characteristics of consumers and the patronage of cooperative for household food security.

\subsection{Study area}

\section{Materials and Methods}

This study was carried out in Ekiti State, Nigeria which lies within the tropics between longitudes $4^{\circ} 45^{1}$ and $6^{\circ} 45^{1}$ East of Greenwich meridian and latitude $6^{\circ} 15^{1}$ and $8^{\circ} 5^{1}$ North of equator. The state experiences a typical tropical climate with two different seasons, raining season between April and October and also dry season between November and March. The State shares boundary in the South with Kwara and Kogi States, in the east by Ondo State and west by Osun State. Having population of 2,384,212, which represent about $1.7 \%$ of the nation's total population with covered land area of $6,353 \mathrm{~km}^{2}$ [7] [8], average annual rainfall ranges between $2000 \mathrm{~mm}-2400 \mathrm{~mm}$, the temperature range from $20^{\circ} \mathrm{C}-27^{\circ} \mathrm{C}$ and $60 \%$ relative humidity, with sixteen (16) Local Government Areas. Ekiti State was purposively chosen for the study due to the escalation of cooperative societies in the State and effort to salvage people from famine and poverty.

\subsection{Sampling technique}

A total of 120 civil servants from six different consumer's cooperative societies were randomly selected and interviewed for this study. Data were collected on socio economic characteristics of respondents such as age, marital status, educational level, sex, household size, membership of cooperative society and level of income using structured questionnaire. Information was collected on efforts made by members of the societies to ensure food security and sustainability.

\subsection{Methods of data analysis}

Data were analyzed with the use of descriptive statistics such as frequencies distribution, mean, standard deviation and percentage to determine the socio economic characteristic. Dietary diversity measure was also used to classified respondents into food secure and food insecure class [9] [10]. A food secure benchmark of 0.5 was determined based on how varied diets of respondents. Respondents with benchmark greater than 0.5 are classified as food secure (1) while benchmark less than 0.5 are classified as food insecure (0).

\subsection{Probit model}

This was also used to determine the probability relationship between food security status and membership of cooperatives of the respondents.

$\operatorname{Pr}(\mathrm{Yi}=1)=\mathrm{f}(\beta \mathrm{XXi})+$ ei

Where

$\mathrm{Y}$ is a dichotomous dependent variable with value of 0 or 1 to measured food security status of respondents. Food secured (1) and food insecure (0).

$\mathrm{Xi}=\mathrm{n} \times \mathrm{k}$ matrix of independent variables.

$\beta \mathrm{i}=\mathrm{k} \times 1$ estimated coefficients.

ei $=$ error term.

\subsection{Socioeconomic characteristics of the respondents}

\section{Results and Discussion}

Table 1 shows the distribution of respondents based on their socio economic status. The average age of respondents was 46.92 years with standard deviation 9.29 . However, $39.17 \%$ of the respondents were within the age range of 41 to 50 years which depicts that they were within the active age range and in which they also make up the highest percentage. $69.17 \%$ of the respondents were married, $74.14 \%$ were graduates in which they acquired formal education. The average household size of 3.43 shows that the respondents have minimum household size and 52.5\% of the respondents have household size between the ranged of 4 to 6 number. Meanwhile, $72.5 \%$ were female, $88.33 \%$ of the respondents (106 people) were members of consumer cooperative society with distinct names while the remaining $11.67 \%$ of the respondents (14 people) are not members of consumer cooperative society because their wife is also a member in their place of work. The average monthly income of the respondents was $38,046.55$, with more than half $52.5 \%$ of the respondents falling between the monthly income $40,001.00$ to $60,000.00$. $60.37 \%$ of the respondents patronize consumer cooperative during festive periods, $31.14 \%$ patronize monthly while $8.49 \%$ patronize quarterly bases for their household food needs. 
Table 1. Socio economic characteristics of respondents

\begin{tabular}{|c|c|c|c|c|}
\hline Variables & Frequency & Percentage (\%) & Mean & StandardDeviation \\
\hline \multicolumn{5}{|l|}{ Age (Years) } \\
\hline Less than 30 & 14 & 11.67 & & \\
\hline 31 to 40 & 34 & 28.33 & 46.92 & 9.29 \\
\hline 41 to 50 & 47 & 39.17 & & \\
\hline 51 to 60 & 25 & 20.83 & & \\
\hline \multicolumn{5}{|l|}{ MaritalStatus } \\
\hline Married & 83 & 69.17 & & \\
\hline Unmarried & 37 & 30.83 & & \\
\hline \multicolumn{5}{|c|}{ EducationalQualification } \\
\hline $\mathrm{BSc} / \mathrm{HND}$ & 89 & 74.17 & & \\
\hline OND/NCE & 18 & 15 & & \\
\hline Others & 13 & 10.83 & & \\
\hline \multicolumn{5}{|l|}{ Sex } \\
\hline Male & 33 & 27.5 & & \\
\hline Female & 87 & 72.5 & & \\
\hline \multicolumn{5}{|l|}{ Householdsize } \\
\hline 1 to 3 & 40 & 33.33 & & \\
\hline 4 to 6 & 63 & 52.5 & 3.43 & 1.98 \\
\hline 7 to 9 & 17 & 14.17 & & \\
\hline \multicolumn{5}{|l|}{ LevelofIncome (A) } \\
\hline Less than 20,000 & 9 & 7.5 & & \\
\hline 20,001 to 40,000 & 23 & 19.17 & $38,046.55$ & \\
\hline 40,001 to 60,000 & 63 & 52.5 & & \\
\hline Above 60,000 & 25 & 20.83 & & \\
\hline \multicolumn{5}{|c|}{ MembershipofCooperative } \\
\hline Yes & 106 & 88.33 & & \\
\hline No & 14 & 11.67 & & \\
\hline \multicolumn{5}{|l|}{ PatronageofCoop } \\
\hline Monthly & 33 & 31.14 & & \\
\hline Quarterly & 9 & 8.49 & & \\
\hline Festive period & 64 & 60.37 & & \\
\hline
\end{tabular}

Source: Field survey, 2014

\subsection{Influence of consumer cooperatives on food security}

Table 2 shows Membership of Consumer Cooperative societies have positive significant influence on food security status of the respondent, it also increase the probability of food security among respondent by about $12 \%$. Level of education, marital status and level of income also has positive significant influence on food security status of the respondents. Educational status increases the probability of being food secured by $23.2 \%$, Level of income increases the measurement of the probability of being food secured by $62.3 \%$, marital status increases the measurement of the probability of being food secured by $40.2 \%$. However, household size shows negative significant influence on food security status of the respondents. The unit increase in household size will increase the level of household food insecurity by $58.6 \%$.

Table 2. Estimate of probit regression model

\begin{tabular}{|c|c|c|}
\hline Variables & Coefficients & StandardDeviation \\
\hline Age & -0.321 & 0.131 \\
\hline Sex & 0.191 & 0.381 \\
\hline Marital Status & $0.402^{* *}$ & 0.203 \\
\hline Household size & $-0.586^{*}$ & 0.255 \\
\hline $\begin{array}{c}\text { Membership of } \\
\text { Cooperative }\end{array}$ & $0.120^{* *}$ & 0.017 \\
\hline Income Level & $0.623^{*}$ & 0.186 \\
\hline Level of Education & $0.232^{* *}$ & 0.102 \\
\hline
\end{tabular}

Source: Data analysis, 2014

* Significant at $5 \%, * *$ significant at $1 \%$

\subsection{Reasons for patronizing cooperative societies}

Table 3 shows the rating of important reason for patronizing cooperative society starting from the most important reason to the least in order of ranking, cheaper price, payment is easy, dividends, payment of children's school fee, saves time and promotion of cooperation among members. The findings implies that cooperative societies should find more ways of making bulk purchase and/or direct purchase of food items and other household consumer goods to further enjoy reduced prices to the benefits of their members. 
Table 3. Reasons for patronizing cooperative societies

\begin{tabular}{|c|c|c|c|c|}
\hline Ratingimportanceofcooperative & Importantindex & Mean & StandardDeviation & Rank \\
\hline Cheaper price & 3.80 & 1.00 & 139 & $1^{\text {st }}$ \\
\hline Dividends & 3.10 & 1.35 & 54 & $3^{\text {rd }}$ \\
\hline Payment is easy & 3.21 & 1.19 & 84 & $2^{\text {nd }}$ \\
\hline $\begin{array}{c}\text { Promotion of cooperation among } \\
\text { members }\end{array}$ & 1.64 & 1.01 & 10 & $6^{\text {th }}$ \\
\hline Saves time & 2.45 & 1.14 & 25 & $5^{\text {th }}$ \\
\hline Payment of children school fees & 3.00 & 1.30 & 52 & $4^{\text {th }}$ \\
\hline
\end{tabular}

Source: Field survey, 2014

\section{Conclusion}

This study evaluates the pertinent patronage of consumer cooperative societies among civil servants in Ekiti State to ensure food security and sustainability. It also assess the influence of cooperative on food security, reasons for patronizing cooperative society for household food and other consumer's need, ranking the importance of cooperative to household food security and also the significant relationship between the socio economic characteristics of consumers and the patronage of cooperative for household food security. The study shows that patronage of cooperative societies has significant effect on food security among the civil servants and the main reason for patronage is the advantage of reduce prices benefited by members compared to open market prices.

In order to increase the impact of consumer cooperatives in ensuring food security among the civil servants the following recommendations were made:

(i) Members of consumer cooperative should be motivated among civil servants.

(ii) Consumer cooperative should strategize means of giving low price benefit to their members.

(iii) The executives of consumer cooperative should look for safer and easier method of repayment of members' debt without violating the unity among them.

(iv) Dividends should be equally distributed as at when due to motivate members patronage.

\section{REFERENCES}

[1]. F. S. Idachaba, Food Security in Nigeria: Challenges under democratic dispensation. 9th ARMTI Annual Lecture, Ilorin, 24.3.2004

[2]. Food and Agriculture Organization, The state of food security in the world: Economic Crises-impacts and lessons learned. 2009, Retrieved from http://www.fao.org/docrep/012/i0876e/i0876e00.htm

[3]. L. Direnberger, Gender and food security: Inequalities in relation to hunger. Genre en Action Bulletin, $2008,7$.

[4]. World Bank, Poverty Reduction and the World Bank.Washington, USA, 1996, 53

[5]. A. A. Ladele andG. B. Ayoola, Food marketing and its roles in food security in Nigeria, In Shaib, B., Adedipe, N. O., Aliyu, A. and Jir, M. M. (eds). Integrated Agricultural Production in Nigeria; Strategies and Mechanisms for Food Security. Proceedings of the National Workshop on Nigeria Position at the World Food Summit, Abuja, Nigeria, 1997, 88

[6]. G. M Adedoand C. O. Ajewole, Consumer cooperatives, food security and the sustainability of civil servants in urban cities of Ondo State, Nigeria, Journal of Food, Agriculture \& Environment. 8 (3\&4). 2010, 202-206.www.world-food.net

[7]. National Bureau Statistics, Nigeria core Welfare Indicators. NBS, Abuja, Nigeria. 2008, 34

[8]. National Population Commission,www.onlinenigeria.com2006, (Accessed on 18th February, 2014)

[9]. T. Ruel Marie, Is dietary diversity an indicator of food security or dietary quality? FCND Briefs 140, International Food Policy Research. Washington D.C, 2002

[10]. J. Hoddinott and Y. Yohannes, Dietary diversity is associated with child nutritional status: Evidence from 11 Demographic and

[11]. Health Survey. FCND Briefs 140, International Food Policy Research, Washington D.C, 2002. 